\title{
Psychology and Religion. Remarks from a Methodological Perspective
}

\author{
JAN F. TERELAK \\ Cardinal Stefan Wyszynski University in Warsaw \\ j.terelak@uksw.edu.pl \\ ORCID: 0000-0002-8884-9409
}

\begin{abstract}
The paper is an overview of the connections between scientific psychology and religion. The thesis that scientific psychology, which deals with empirical research of all manifestations of spirituality and religiousness within the different principles and contexts of culture, cannot refer to the doctrine of Christianity, just as to other religions of the world, but it should take into account in its research the cultural aspects of the Christian religion and/or other religions - without valuing tchem at the individual human level (personalistic psychology) and their influence on the "fate" of the world (e. g. cultural psychology), is being discussed.
\end{abstract}

Keywords: scientific psychology; religion; spirituality; methapsychology; personalism; methodology.

\section{Background}

From the very beginning, psychology - first speculative and now empirical - has been entangled in two cognitive trends (called the "parents of psychology”): philosophical and biological, which entailed endless discussions 
regarding psychophysical isomorphism, manifested e.g. the in three concepts of the Austrian ethologist Konrad Lorenz (1966):

(1) The concept of interaction between the "soma" and the "psyche" - assuming that somatic phenomena can be considered as the cause of adequate experience and assuming that they in turn affect physiological processes, is based on a cause and effect relationship, which is devoid of logic.

(2) The concept of identicalness of the "soma" and the "psyche" - it assumes that somatic and psychological phenomena are simply the same "real in themselves" and that we experience one and the other (as in the case of matter and energy) through independent, diverging methods of cognition, it is most justified in the use of physiological methods in psychology and psychosomatics, as "psyche" correlates.

(3) The concept of psychophysical parallelism - emphasizing the parallel course of two chains of events, between which there is no logical link, since nobody denies that all mental processes are accompanied by neurophysiological processes, but in no way can this statement be reversed. One of the most famous variants of psychophysical parallelism is the Cartesian "psychophysical dualism" (the so-called Descartes' Error), which contraposed the res extensa (physical object) and the res cogitans (thought object), thus taking the position that reality is made up of two fundamentally different substances, functioning on different principles: the material world - based on mechanical principles and the spiritual world - based on freedom.

Both these types of substances, being divergent, meet in the human being. As an advocate of Platonic spiritualism, Descartes described the relationship between the spiritual and the physical substance as follows: "Man is a soul that uses the body" (Homo est anima utens corpore) (quoted from: Damasio, 1999). This antireductionist approach to scientific psychology is still causing many methodological problems, explaining the relationship between science and faith. The limits of the dispute between contemporary scientific psychology and the Christian idea go back to 19th century positivism and 20th century American pragmatism. This first positivist aspect of the dispute was, among other things, a consequence of the 19th century philosopher Comte (creator of the notion of positivism), 
who had great influence on the detachment of humanities from theology and metaphysics. According to Comte's views, more important than the paradigm is the methodology, which has become the only criterion for dividing science into formal (logic and mathematics) and empirical (natural and social sciences). Among the empirical social sciences is psychology, with its specific research methods. Thus, positivism placed the emphasis on explaining and predicting phenomena and avoiding answering the question "why?". In turn, the pragmatism in American philosophy, while promoting the instrumental vision of knowledge (science), assumed that truth is nothing but the power of our ideas, requiring empirical confirmation and revision of traditional philosophical dualisms: mind/body, nature/culture, fact/value, idealism/realism, subject/object, individual/society. Both these trends were responsible for the development of twentieth-century psychology in the form of such theories as American behaviorism, Freudian psychoanalysis and finally one dimensional cognitive psychology, as well as interdisciplinary cognitive science and mathematical psychometry.

\section{The methodological canons of psychology}

The methodological canons of psychology limiting the study of the relationship: science - faith. Let us note that within the Vienna Circle ${ }^{1}$, the so-called logical empiricists with Ernest Machem at the forefront, rejected all metaphysical elements and saw the origins of cognition only in pure

1 The third positivism (neo-positivism) was created in the twentieth century in Vienna, where - at the seminar of M. Schlick - the "Vienna Circle" (Der Wiener Kreis) was constituted in 1923, grouping philosophers and theoreticians of science, such as M. Schlick, R. Carnap, Ph. Frank, O. Neurath, K. Popper, K. Gogel, with a program involving combating metaphysics, promoting the postulates of empiricism and physicalism, among which the most important are the following: (1) the treatment of mathematics and logic as non-empirical and analytical sciences; (2) the reduction of all empirical sciences to a single entity on the basis of physical language; (3) the reduction of the humanities to psychology and sociology, both perceived in behavioral terms; (4) the elimination of metaphysics, the issues of which are apparent and the claims - pointless; (5) the elimination of other philosophical sciences - the theory of cognition, ethics, aesthetics - and leaving philosophy only as a means to analyze language (quoted from: Stadler, 1998, pp. 606-616), distinguishing empirical sciences from ideology (quoted from: Thornton, 2016). 
facts, which were reported by means of "protocol tasks" and for which the criterion of veracity was verification. Sir Karl Raimund Popper, a philosopher of science and creator of the philosophical system known as "critical rationalism" (which he considered to be a continuation of Immanuel Kant's philosophy), significantly limited this search for data confirming the theory (verification) when he introduced the principle of multiple falsification according to the scheme: description (the world of facts) - explanation (the world of theory) - prognosis. Thus the scientific method can only consist of deduction, motivated by the permanent Cartesian doubt, according to the known principle of "Dubito ergo cogito, cogito ergo sum". These doubts characterize all the hypotheses with a dose of certain probability, which only partially bring us closer to the accurate description of reality, especially since the selection of the examined group should be random and not purposeful, which is especially a difficult task in social sciences. These strict methodological rules of science, which hamper the desire to quickly and unambiguously learn the truth about man and the world around him, are well illustrated by Popper's example of a deduction from the observed pack of swans regarding their color, according to which the observation of a hundred swans does not prove that all swans are white and the observation of a single black swan defies this thesis (cf. Stokes, 1998). And so, Popper believed that, unlike true science which creates falsifiable theories, concepts such as Marxism or psychoanalysis are pseudo-scientific in their nature, because their structure is such that they are able to "explain" every fact without being able to test their experimental validity. In the case of psychoanalysis, falsification cannot be used, as it explores highly subjective phenomena that refer to imagination. It also pertained to the cognitive trend in the initial stage of the development of scientific psychology, namely introspection, as the only method of learning subjective states of things.

The methodological canon of falsification of hypotheses makes that even Christ as God in person cannot be the subject of psychological research, because it would be just a "case study". However, the description itself does not fulfill the criterion of science without two other functions: explanatory and predictive. Therefore, every religion as such, exceeds the possibilities 
for direct research in scientif psychology, which is a posteriori in nature, according to the Latin adage „Primum vivere, deinde philosophari”, emphasizing that the basis in psychology is empirical research, not a priori dogmatic assumptions.

The description of the relationship between psychology and religion requires reflection, because both psychology and religion are two autonomous spheres of human life, each of which has its own specificity, which cannot be achieved in the other. You can for K.I. Pargament (ed.) (2013) pose a fundamental question: How can psychologists integrate religion and spirituality within various models of assessment and treatment? In particular, psychology as a science does not have and cannot have assumptions derived from other cognitive means (e. g. supernatural phenomena) than those legitimized by the methodology of psychology. Therefore, it cannot accept assumptions derived from any religion. In short, there is no psychology with the Christian, Islamic, Buddhist or other adjective, which does not mean that the issue of psychology and religions is not worth considering more broadly, e. g. from the metapsychological perspective, i. e. from the perspective of different concepts of psychology and different understanding of spirituality, such as applied psychology and psychotherapy in relation to religion as a cultural phenomenon (Lines, 2006, Dixon, 2018). Of course, describing religion and spirituality as elements of culture has its limits, which draws attention A. Farman (2019) on the example of transhumanism, which „adopted terms like religion and spirituality to denote their own groups and goals and describe their metaphysical forays" (Farman, 2019, p. 57).

\section{The metapsychological perspective of the relationship: psychology - religion}

Metapsychology literally means "parapsychology" and non-scientific psychology, going beyond empirical data and referring to supernatural phenomena. Kahneman, D., Slovic, S.P., Slovic, P., Tversky, A. (1982). desire to search for an easier way of cognition, called "short-cuts" cognition, chosen to distance oneself from parapsychology, ideology or religion is 
understandable. Motivations to choose this route need not necessarily be irrational, as is the case for modern businessmen who are more likely to employ parapsychologists (astrologists, clairvoyants, etc.) as business advisors because of quick and unambiguous decisions compared to business psychologists who work slower and suggest business decisions only with a certain probability of risk. A question arises: If psychology as a science is completely helpless on the methodological level, is it automatically useless for addressing difficult existential issues? I think that a certain attempt to approximate two methods of cognition: science and faith, while maintaining full autonomy, may be a metapsychological perspective, renouncing parapsychology and understood as an attempt to synthesize the most general, universal principles of psychology. This approach is nomothetical as opposed to an idiographic one, which focuses on specifics, an individual or a particular theory (Hood, Belzen, 2013). Thus, it is a way of synthesizing facts, theories and speculation on the principle of heuristics, meaning mental readiness to detect relations between new facts. Unfortunately, heuristics as a method of formulating "short-cut" judgments, is a group of practically proven (but not always consistent with theoretical knowledge) for own use relationships between various aspects of reality. Although this method, which is characterized by an effective and fast way of issuing judgments, may lead to discovering new properties of the studied object or many basic features not yet known, but this sometimes leads to simplified rules of conclusion, generating certain cognitive errors.

A. Tversky and D. Kahneman (1974) characterized several such cognitive "shortcuts" in the 1970s, as e.g.: (1) the heuristics of availability - meaning that a judgment is made on the basis of how easily something comes to our mind; (2) the heuristics of anchoring - using some, sometimes arbitrary, value as a starting point for adapting our assessment, modifying it, but in an insufficient way; (3) the heuristics of representativeness involving classifying something on the basis of its similarity to a typical case; (4) the heuristics of simulation, which makes events that can be easily imagined seem more likely to occur, and their adverse effects are assessed more negatively. These aythors warn not to identify similarities with probabilities 
and remind that when assessing probabilities, scientists treat similarity as an overarching variable (e.g. a metafeature) in relation to so-called a priori probabilities, results, often ignoring the a'posteriori (empirical) aspect. As L.W. Busenitz and J.B. Barney (1997) claim, this also applies to heuristics, known as the "short-cut" method, which is a group of proven (but not always theoretically compliant) relationships for one's own use between different aspects of reality, which is characterized by an impressive and fast way of judging, but which leads to many errors. The use of heuristics may lead to the discovery of new properties of the object being studied or of many previously unknown basic features.

According to D. Kahneman, et al., (1982), a significant weak point of heuristics is the very mechanism of probabilistic reasoning hidden in the heuristics of adaptation and anchoring, which is well described in economic psychology in the form of the theory of usefulness of transaction, which is well illustrated by e. g. the behavior of consumers who compare the discount price of a given product with the target price (e.g. broken down into installments).

\section{Errors in the description of the relationship between metapsychology and religion on the example of Christianity}

Errors in the description of the relationship between metapsychology (different concepts of psychology) and Christianity are also a result of a different understanding of Christianity as a doctrine, a way of being a Christian or finally Christian tradition as the foundation of culture:

a) The Christian doctrine, having its foundation in revelation, that is to say, the knowledge of God, man and the world from a divine point of view, is not born from the exploratory and explanatory curiosity of science, but from the question of the meaning of existence and the essence of salvation. Christian doctrine, like all other religious doctrines, is to be a specific "guide" on man's way to God (to salvation), and not an answer the question of the structure and functioning of the world, including the human psyche 
(Jaworski, 2006)). This is illustrated well by the following antinomies: (1) God vs. man; (2) divine grace vs. intelligence; (3) sinful human nature vs. free man; (4) free will vs. situationism; (5) hope for an afterlife vs. temporality; (6) holiness vs. success; (7) divine moral laws vs. Moral relativism; (8) divine support vs. social support; (9) possession by Satan vs psychiatric casus; (10) religious practices vs. magical behavior; (11) miracles vs. illusions; (12) transverberation vs mystification or mental illness (Wasiukiewicz, 2015, p. 54.). A historical example of a clash of narratives concerning the phenomenon of Father Pio's transverberation from two perspectives: Christian and scientific is the casus of Father Agostino Gemelli, a Franciscan, physician and psychologist and rector of the University of Milan, who for half a century was the greatest scientific authority of the Italian Church, he called the stigmatic Father Pio the "mystic of delusion", and his wounds he recognized as a symptom of hysteria and self-mutilation, which was the reason why he stopped the beatification process for a while (Debè, Polenghi, 2019). This suggests that attempts to demolish the autonomy of both religious and scientific narratives sometimes lead to ideology being honored at the expense of rationalism, as illustrated by the situation of the eminent French anthropologist, paleontologist and philosopher Pierre Teilhard de Chardin, creator of the theory of evolution, who tried to give it a new philosophical meaning in the spirit of Christianity (the so-called Christian evolutionism) at the end of his life, influenced by the criticism from traditionalist Catholic circles. He claimed that the whole reality has a dynamic and evolutionary nature, aspiring from the point of Alpha to the point of Omega, having its beginning and end in the person of Jesus Christ. The purpose of the world and man is mystical union with God (quoted from: Waloszczyk, 2016). Thus, Christianity understood dogmatically and scientific psychology (similarly to other scientific disciplines) find a place for themselves as autonomous areas, polarized at the ends of the continuum of cognition (Sarah, et al., 2019).

b) The way of being a Christian includes living according to certain principles of faith (the Decalogue) and its behaviors, including among others: forms of worship, moral life, the level of identification with the Christian 
doctrine, etc. This aspect of Christianity, as well as of other religions, is the subject of scientific research into the psychology of religion or spirituality, e. g. in the field of: cognitive beliefs, generosity, mercy, gratitude, etc. or religious behaviors and practices, including e. g. prayer, meditation, church service, reading inspiring writers, charity, altruism, service to others, etc. (Cohen \& Hill, 2007).

Referring to ontology, one can follow the outstanding Polish philosopher M.A. Krąpiec (2005) and take note of the cognitive process of a human being, in which two aspects of the genesis of cognition can be distinguished, i.e. the activity of introducing information about something into the field of human consciousness: (1) the direct sensual-intellectual cognitive act relating to the perception of the ownership of individual facts is called an experience or observation; (2) the indirect intellectual cognitive act refers to the relationship of content between concepts as a basis for judgments or the relationships between the contents of the judgments. Because transcendent existence (a deity, God) cannot be recognized through a direct observation, therefore the sensual-conceptual human being, preferring contextual thinking, based on the mechanism of cognition by analogy, requires a myth on a transcendental (virtual) level. The psychology of religion identifies many mythological states of mind, such as: charisma, intuition, feeling, clairvoyance, visionariness, superstition, horoscopes, mysticism, charms, different states of consciousness, delusions, stigmatization, etc. (Hood, 2008). Mythological thinking does not describe events but is only a subjective narrative about the influence of supernatural forces on a human being. Scientific psychology may know the partial goals of a human being but without objective reference to universal goals, because it is unable to answer basic existential questions about the meaning of an individual's life, although the subjective narrative about the influence of supernatural forces on human fate is the object of inquiries of experimental existential psychology (Greenberg, Koole \& Pyszczynski, 2004) and the psychology of religion (Paloutzian \& Park, 2015).

The examination of the way of being a Christian from the perspective of normative models must take into account the significant differences 
between normative objectivity, based on the assumption that man as an entity implements norms independent from him, originally established in relation to cognition (e. g. divine law, the Decalogue) and normative subjectivity, placing man as the creator of norms, which can be constructed by quantitative and qualitative methods (Prinz, 2009). The representatives of two different approaches to the understanding of human moral norms, considered at the level of value systems, are, among others, the German phenomenologist Max Scheler and the American social psychologist Shalom H. Schwartz. And so M. Scheler, the creator of the term "homo religiosus", understood objective values that are intuitively perceived, within the framework of an a priori, superhistoric hierarchy, where such values as: spiritual (aesthetic, cognitive, values of the legal order), vital, hedonistic, utilitarian (useful), are governed by religious values (divinity and holiness), which are at the same time the basis of all axiological acts. (quoted from: Smith, 2010). In turn S.H. Schwartz (2011) is in favor of the a'posteriori approach to describing the impact of different contemporary civilizations and cultures on the system of human values, as evidenced by the fact that he is the coordinator of an international research project covering more than 70 countries, over individual differences in the structure of the system of values in relation to local cultures, religions and social systems (Cohen, Hill, 2007). Both of the proposed models of the structure of contemporary human values are preferable to various qualitative (narrative) and quantitative (psychometric, neurophysiological) research methods (Smith, 2010; Anczyk, et al., 2019). An example of the verification of Scheler's concept of "homo religiosus", based on the assumption that religious values are feelings of "love for God", is the attempt to seek empirical level answers to the question: Can religious feelings be examined? Religion psychology is dominated by the position that religious feelings do not exist as a separate category of emotions, so in terms of the subjective state of feelings, expression of religious feelings (on the level of neurophysiological research), they cannot be distinguished from non-religious ones (Emmons, 2005). Thus, for example, studies related to brain imaging have shown that God is experienced in the brain as a social bond, because believers who are asked about God activate 
the same region of the brain as when asked about a friend (Schjoedt et al., 2009). Thus, we refer to religious feelings when they appear in a sacred context (in the church, synagogue, mosque); as a result of performing rituals (e.g. the liturgy); as a result of identification with one's religion; when one considers certain emotions to be important for contact with God (ecstasy, different states of consciousness); when believers give religious meaning to "everyday" emotions because of the sacral perception of the sense of life and theworld (the so-called sacred values) (Atran \& Ginges, 2015; Paloutzian \& Park, 2015).

c) The Christian tradition, the basis of which is a system of values resulting from the Christian doctrine, it manifests itself throughout history in very different cultural codes, which provide a lot of information for scientific psychology about a man who has difficulty imagining the deity. This is particularly reflected in the anthropomorphism present in Christian iconography, which takes into account the sensual-intellectual nature of the human cognition process. We can trace this on the example of how the Magisterium of the Catholic Church takes into account the sensual-intellectual nature of the "personal God" both at the semantic level (e.g. "God descended to Earth...”, “The Holy Spirit inspired the Prophets”, etc.) and in the iconography, presenting e.g. The nature of the Holy Trinity, in which "God the Father" - the experienced and caring old man, "Christ the Pantocrator" - the Lord of all things with a monarchy-like rule (often in wearing a crown) and "The Holy Spirit - the dove moving in three dimensions of space-time (Feuillet, 2006). They allude on the one hand to the Judaeo Christian culture and on the other to specific (civilizational, national) cultures and are spread all over the entire globe through missionaries, affecting the axiology of people over the last 20 centuries (Makowski, 2017). This was pointed out, among others, by Jean-François Colosimo (2015), a lecturer at the Orthodox Institute of St. Serge in Paris, according to which Christians created the historical process of Islamic-Arabic development through their contribution to philosophy, art, architecture, etc., e.g. traces of Babylonians in Assyrians or traces of the Pharaoh's Egypt in Koptas (e.g. the Aramaeic language liturgy). These Christian cultural codes are modified 
in different historical periods as to form, but they always oscillate around the doctrine, which is appreciated in the well-known formula: "Ecclesia semper reformanda est". We owe to Christianity in this sense, on the one hand, i.a. the separation of certain spheres of human activity into the profanum and the sacrum, which are concentrated in a specific human being, and on the other hand, the culture manifested in the antinomy "give therefore to the emperor the things that are the emperor's, and to God the things that are God's". The location of science on the profanum side, on the one hand, makes it possible to appreciate the autonomy of science in relation to religion, which does not necessarily imply hostility or contradiction with the sacrum, which is very easily emphasized in the "Fides et ratio" Encyclical by its author John Paul II. (1998), and also the great Polish scientist: cosmologist, philosopher, physicist and mathematician, professor M.K. Heller (2008) - specializing in the philosophy of nature, physics, relativistic cosmology and the relationship between science and faith, according to whom faith is the answer to great civilization questions that science cannot and probably will never be able to answer, originating from the fields of metaphysics, epistemology and axiology: (1) Why is there something rather than nothing? (the so-called Leibniz question); (2) How to rationally justify rationality? (Popper's ethical dilemma: the necessity to use the intellect cannot be defended intellectually); (3) How are values possible? (truth, beauty and goodness are universal in their nature and therefore testify to the existence of transcendence, because they cannot be scientifically explained - a reference to Kant). This thought construct refers to the platonic distinction between "objective knowledge" (episteme) and "subjective opinion" (doxy) about reality, but the difference is that John Paul II treats the elements of this antinomy in a complementary way, while Plato treats them in a mutually exclusive way. Father Hans Küng (1990) - a Swiss Liberal, professor at the University of Tibing, founder and president of the "Weltethos" Foundation ("Ethos of the World"), who wants to construct a global ethic of the contemporary world on the basis of systems of values of great religious traditions, has been trying to answer the third question, so far with no avail. If this has not yet been achieved at a global level, 
the history of the world knows many cases of "local universality" within a specific civilization, such as that of Christianity among Europeans, as evidenced, inter alia, by the inclusion of the "Christian tradition" as an axiological basis in the preamble to the Charter of Fundamental Rights of the European Union.

Aside from the Christian doctrine, we must accept that the psyche of a Christian and a religious human being in general is the object of psychological research and can also be part of the convictions of a particular psychologist, which does not mean that there exists Christian psychology per se. As has already been said, psychology as a science has its own peculiarity, different from any religion, including Christianity, whereas the methodology of psychology as a natural science, i. e. one that utilizes and confines itself to natural cognitive powers of man, excludes any reference to any religious dogma. There is in fact a tendency to put the thesis of correspondence between natural and supernatural justifications, although this does not seem to be the case when it comes to psychology, and therefore a psychology with the adjective "Christian" is excluded from scientific psychology, but the same goes for any other ideological adjective, such as "Marxist psychology" in the past. Thus, the reduction method, which seeks to reduce science and Christianity to a third autonomous scientific discipline, is an abuse. If this "third way" were to be reduced to a "Inspired by Europe's cultural, religious and humanist legacy, from which universal values derive, constituting inviolable and indelible human rights, as well as freedom, democracy, equality and the rule of law" (Preamble to the EU, 12, 2004). Of course, describing religion and spirituality as elements of culture has its limits, which draws attention A. Farman (2019) on the example of transhumanism, which "adopted terms like religion and spirituality to denote their own groups and goals and describe their metaphysical forays" (Tarma, 2019, p. 57). An example of the fact that at heuristic level Christian aspects can be included in psychology is the renaissance in recent years of psychology of spirituality, which has its roots in the so-called Humanistic psychology, which is not a psychological theory but certainly an effective psychotherapeutic practice. 


\section{Humanistic psychology as a theory of psychotherapy based on Judeo-Christian axiology}

Regardless of the main development trends of the 20th century scientific psychology of religion for which the paradigm was more important than the phenomena studied, the personalistic theoretical reflection of psychologists, which was undoubtedly influenced by Judeo-Christianity, also increased (Paloutzian, 2017). The motivation to take such a position was seen in the epistemological distinction of "thinking” from "cognition" (Krokos \& Mazanka, 2008). The first one is a pure description of the relationship between beings, while cognition seeks rules for explaining these relationships, i.e. it seeks a broadly understood "truth" about the world and not enclosed in a particular paradigm. These psychologists were aware of the fact that contemporary psychology, apart from the psychometric description of the situation, is not able to offer a thorough explanation of the essence of humanity (Wood, et al., 2010). From a metapsychological perspective, it would be possible only at the heuristic level, but no way at the methodological level. An example of the fact that, on the heuristic level, Christian aspects can be taken into account in psychology is the renaissance in recent years of the psychology of spirituality, which has its roots in the so-called humanistic psychology, which is not a psychological theory, but certainly an effective psychotherapeutic practice (cf. Frankl, 1997).

Gordon Allport, a classicist of contemporary personality psychology, drew attention to this fact as early as in the 1940s, who together with such co-founders as e.g.: Charlotte Bühler, George Kelly, Carl Rogers, established in the 1950s an intellectual metapsychological trend called the "Humanistic Psychology" or the "Third Power of Psychology" (next to behaviorism and psychoanalysis) (Nicholson, 1997). Let us recall here that this trend was a reaction, on the one hand, to the First and Second World War, which devastated Europe of the 20th century both physically and morally. This "devaluation" of Christian values and the pessimistic existential philosophy of Sartre (1973), which undermines the meaning of existence (You were born without meaning, you live without meaning 
and die without meaning) was the cause of social trauma on a huge scale, going far beyond the borders of Europe. Scientific psychology, with its methodology for the diagnosis of traumatic situations, has lost its usefulness in relieving people from suffering. Therefore, the practicing psychologists' idea of creating the theoretical foundations for a system of psychotherapy, referring to universal values such as: love of freedom (Erich Fromm), the need for self-realization, the transcendence resulting from the existence of higher beings (Abraham Maslow), self awareness (Carl Rogers), etc. Humanistic psychology, treating the human being as an autonomous subject, in terms of theory refers to existentialism, personalism and phenomenology, and methodologically, it places emphasis on researching the current human experience. Humanistic psychology, focusing on subjectivization of the research situation, dialogged with the research subject rather than their manipulation, rejects beliefs about the situational determinism typical of behaviorism and biological determinism characteristic of psychoanalysis, it puts emphasis on intrasteerability, the primary goal of which is the need for self-updating and unrestricted choice of behaviors (freedom) ${ }^{2}$.

The problem of free will and responsibility for oneself and others therefore arises again. It can be illustrated by the efforts of 20th-century psychology, which tried to solve the problem of free will on three levels: physiological, experimental and personalistic.

(1) The physiological plane based on biological determinism (e.g. psychoanalysis), justified the rejection of the construct of free will, citing the lack of evidence of the existence of neurophysiological mechanism in brain structures, although Sir Charles Scott Sherrington, a Nobel Prize laureate in the field of physiology and medicine in 1932 for discovering the function of neurons, emphasized that the problem of dependence of spiritual processes

2 In Poland, similar ideas of humanistic psychology were used, in addition to Antoni Kempiński, by a neurologist, psychiatrist and psychotherapist, Kazimierz Dąbrowski (1902-1980) in his concept of mental hygiene based on the so-called positive disintegration, referring to integrated values around the axiological ideal of the individual and societies. 
on the brain is not only a matter of psychophysiology or medicine, but it is the essence (Persinger, M.A. (1987). This is confirmed by B.T. Wood, et al. (2010) The authors, using functional magnetic resonance imaging (fMRI) to investigate how prayers in believers and non-believers change the brain response, found, among others, that in a group of religious believers, unlike non-believers, strongly activated reactions in temporal-temporal region, medial prefrontal cortex, temporal-parietal junction and precuneus, which confirms the hypothesis that religious, who consider their God to be "real" and able to respond to requests, activate in the brain areas of social cognition during prayer, which from psychological point of view suggests that prayer to the "personal God" (which is theological dogma of Christians) is an intersubjective experience comparable to "normal" interpersonal interaction. (Compare also: Van Elk, 2019).

(2) Determinism is a philosophical concept, assuming that all events and states within accepted paradigms are connected by a cause and effect relationship. The opposite is indeterminism, which assumes that the relationship between cause and effect in nature is not strict, which limits the possibility of predictions of subsequent phenomena on the basis of the earlier ones (the paradigm of chance) and the conclusion that the same causes always lead to the same effects. On religious grounds, the opposite of determinism is free will, understood as freedom of choice, but also dependent on force majeure (fate, God, essential human property) (Butterfield, 1998). Paule Chauchard, a well-known French neurophysiologist, referred to this in the middle of the 20th century, presenting many arguments for the existence of neurophysiological conditions of free will, but the academic circles of the time did not accept tchem (Rzepka, 1972; Brick, Bret, 2008). The second theoretical plane, based on cognitive determinism (behaviorism, cognitive psychology, cognitive science) exaggeratedly accentuated its point of view without due diligence in the search for a place for "free will", emphasizing the concept of motivation regulated, sometimes without thought, by reward and punishment. The third theoretical plane, based on biological determinism. Literature data suggest that, regardless of the connotation of the concept of spirituality in Western Judeo-Christian civilization, mystical and meditative 
experiences are natural and probably measurable processes that are and can be experienced by people of different races, religions and cultures. Those who have spiritual experiences may have different neuropsychological correlates. For the seriousness of the discussion of neuromerebral aspects of discussions on the science-religion relationship, researchers took into account, on the one hand, knowledge of spiritual beliefs and their psychological mechanisms, and on the other, they distinguished "normal" spiritual experiences from pathological states (Newberg and Newberg, 2005).

Therefore, has the problem of "will", which is an attribute of spirituality and which cannot be reduced to biology, ceased to be valid in psychology? No, the search is still going on, I will mention only such theoretical constructs of personality as, for example, the Rotter's "Locus of control” in which the answer to the following question remains unanswered: Is the human being more internally-steered (intentional) or rather externally-steered (situationally determined)? (Kurt, Babar, Kai, 2012).

(3) The psychologists of spirituality inscribe themselves in the third theoretical plane, deriving man's intentionality from a personal perspective, claiming that the full response to this dilemma of contemporary psychology is impossible to unravel without referring to the meaning of human life defined by the values they prefer, which in turn depend on their "subjective acceptance". The leading theoretical role in this respect in Poland is played, among other things, by the Viennese psychotherapist Viktor Frankl (1997), who in the literature of the subject is called "the third classic of European psychology and existential psychopathology”, next to Heidegger's greatest students, who are also influenced by Karl Jaspers, as well as two Helvetians: Ludwig Binswanger (the author of the concept of "being there" - Dasein) and Medard Boss. These authors opposed the aforementioned Sartre's concept of existentialism contained in his main work entitled: "Being and Nothingness", denying in essence the sense of human existence, they proposed a specific "antidote" in the form of "psychology of the sense of existence", in which the key theoretical category is the "will of the sense of existence" (Żelazny, 2011). 
At the turn of the 20th and 21st century, the psychology of spirituality has been developing with a new momentum, building a kind of bridge between scientific psychology and Christianity. This is pointed out by James T. Lamiel (2010), among others, who in answering the question: "Why is there no room for personalistic thinking in psychology in the 20th century?", suggests that one of the reasons for this is the positivist orientation in psychological theories and the excessive attachment to statistical decisions in empirical research (psychometrics). He believes that the 21st century will not only see a return to the personalistic perspective in psychology formulated by William Stern in the first decades of the 20th century, but also to critical personalism and reflection on philosophical anthropology. It should be stressed that there is a certain difficulty in assigning a scientific status to the concept of "spirituality" (Sarah, et al., 2019). First of all, the analysis of the relationship between psychology and Christianity is disrupted by the pseudo-scientific approach to spirituality. The second temptation, which had to be resisted by the psychologists of spirituality, was connected with the necessity of opposing the so-called political correctness, prevailing in Anglo-Saxon psychology, preferring a specific fashion for a neobehavioral and cognitive approach, based on the canon of sociobiology and psychometrics.

The scientific status of the psychology of spirituality and Christianity Psychology of spirituality is not synonymous with Christian psychology, as is it often presented in popular discussions. This is partly due to the fact that the discussion on the scientific status of the term "spirituality" is still open (Watts, 2017). In the first place, the analysis of the relationship psychology - Christianity disturbs the pseudoscientific approach to spirituality ${ }^{3}$.

It is not a coincidence that the renaissance of the problem of freedom of will and spirituality is associated with the civilization trauma of World War II and other wars that have been fought every day in various parts of the

3 Starting to sum up the understanding of "spirituality" for the use of psychology as an empirical science, it should be emphasized that it has nothing to do with esotericism, Freemasonry, gnosticism and "New Age", which began in the 1960s. (Sutcliffe \& Gilhus, 2013). 
contemporary world, because historical research of psychologists of ideas and ethics proves conclusively that the abandonment of ethical categories in times of a decline of spirituality is the cause of dehumanization of entire societies, both in the past and nowadays (Emmons, 2005).

Research on the effects of traumatic stress has shown conclusively that human beings cannot be understood, especially those suffering without their axiological system in situations of existential stress such as extreme terminal or war conditions. This is confirmed by studies of extreme stress carried out, among others, in peacekeeping missions in Bosnia, Iraq and Afghanistan (Truszczyński, Terelak \& Turek, 2000; Tennant, 2007) or in immigrant camps (Palmieri, Marshall \& Schell, 2007). The literature on the subject shows, among other things, that in the face of death causing existential trauma, as well as in the face of a return to the country, the trauma that persists for several months or even years, makes man a "moral cripple”, ruining their hitherto axiological system. It is sometimes impossible for them to reconstruct at all, placing them on the margins of social life. Medicine in such cases is helpless, as evidenced by studies of distant effects of traumatic stress (Delayed Post Traumatic Stress Disorder DPTSD) (Safir, Wallach, Rizzo, 2015). An extreme example of DPTSD is the "holocaust trauma", which is also passed on to future generations (Valent, 2007). Although cognitive-behavioral psychotherapy offers help, it does not generally affect its existential essence, except for lowering the level of excessive emotions (Galanter, 2005; Lines, 2005). This is in keeping with the biblical "archetype of Job's suffering", who, being in an unimaginably difficult existential situation, destroying his hitherto existing subjectivity (his possessions, social status, family and, above all, health) did not receive psychological support from anyone ${ }^{4}$ (Terelak, 2009).

4 As the "Book of Job" says, he expelled the three so-called therapists who visited him: Eliphaz the Temanite, Bildad the Shuhite and Zophar the Naamathite, who "sat on the ground with him for seven days and seven nights. No one said a word to him, because they saw how great his suffering was" $(H, 2,11)$. Job found spiritual peace when he "reconciled with God" (H, 2,11). 


\section{The relationship between psychology religion and spirituality - an attempt of systematization}

To conclude the discussion on the developmental trends in the psychology of spirituality in the context of Christianity, following K. Popielski (1994, 2017), the creator of noologotheory and noologotherapy, it should be emphasized that it is based on three theoretical pillars: (1) intellectual (self-awareness), emotional (empathy), (3) existential (autotranscendence), which form the basis of such spheres of life as: noetic values (the pursuit of values that are important in life), mental values (proper functioning of the psyche), biological values (fitness and health). The increasing presence of teaching and scientific activities of psychologists of spirituality in Polish psychology have led to an acceptance of the view that due to the important role of spiritual experience for a human being and the influence of religion on their functioning, these phenomena should be the subject of a lively interest from scientific psychology. An example of such an interest is the development of the psychology of spirituality not only in Europe, but also in the USA, as evidenced by the declaration adopted by American psychologists during a scientific conference organized by the Institute for Alternative Futures (IAF) on: Total Fitness for the 21st Century, which took place on October 6-9, 2009. It was established that in the composition of the full structure of personality: in addition to such elements as physical, mental, behavioral, health, adaptive, nutritional and social fitness, the spirituality of man must be taken into account as well, defined as: "the essence of human subjectivity, the fundamental part of the self, including th ability to maintain autonomy, self-awareness, creativity and the ability to love and be loved, as well as to understand human beauty and speech". The spirituality defined in such a way consists of the following components, which can be researched empirically through scientific psychology, namely: the structure of values, beliefs and behaviors (e.g. generosity, mercy, altruism, gratitude, etc.), and religious practices (prayer, asceticism, participation in church service, reading the Scriptures, etc.), as well as relations with other religions (e.g. ecumenism vs. religious fundamentalism) and transcendence (e.g. meditations, asceticism, 
etc.) and also with the secular community (e.g. humanitarian support, volunteering, etc.). Since the new political transformation of the 1990s, all these elements of spirituality have been the subject of empirical research also in many Polish universities, enriching Polish and international psychology with new, important information on the functioning of the contemporary human being, approached through the personalistic psychology paradigm yet again (Szydłowski, 2018).

Summing up the previous deliberations, it should be stated that against the background of the twentieth-century Anglo-Saxon psychology, based on the paradigm, there is no place on the basis of valid methodological canons for building a direct relationship between scientific psychology and Christianity. However, the return to philosophical anthropology, approached from a personalistic perspective, initiated by humanistic psychology and developed by psychology of spirituality on the one hand, and Christianity on the other, defined as a centuries-old participant in Mediterranean culture and tradition, makes it possible to revitalize this relationship on the metapsychological, heuristic level on the one hand, and axiological on the other, turning the subject of psychology research into the dignity of the individual.

Distancing oneself from transcendence leads directly to the primitive hedonism of Thomas Hobbes, who in the 17th century proclaimed that man is by nature selfish and evil, but sometimes reasonable in their choices, according to the principle of "better to have or to be". Perhaps the emerging psychology of spirituality, which draws its inspiration from Christian tradition, despite the methodological difficulties, is a notable paradigmatic alternative, especially for contemporary existential stress psychology (Greenberg, Koole \& Pyszczynski, 2004).

\section{Conclusion}

1. Against the background of twentieth-century Anglo-Saxon psychology based on positivist assumptions, it hinders the positive interaction between psychology and study of religion. 
2. The return to philosophical anthropology, approached from a personalistic perspective, initiated by humanistic psychology and developed by psychology of spirituality on the one hand, and Christianity on the other, defined as a centuries old participant in Mediterranean culture and tradition, makes it possible to revitalize this relationship on the metapsychological, heuristic level on the one hand, and axiological on the other, turning the subject of psychology research into the dignity of the individual.

3. Scientific psychology is engaged in empirical research into all manifestations of spirituality and religiousness within the various principles and contexts of Christian culture and/or other world religions - without valuing them - (psychology of religion) and their influence on the "fate" of the world (e. g., the psychology of ideas).

\section{References}

Anczyk, Adam, Halina Grzymała-Moszczyńska, Agnieszka Krzysztof-Świderska, and Jacek Prusak. 2019. "The Replication Crisis and Qualitative Research in the Psychology of Religion." The International Journal for the Psychology of Religion 29(4): 278-291.

Atran, Scott, and Jeremy Ginges, J. 2015. "Devoted Actors and the Moral Foundations of Intractable Intergroup Conflict.” In The moral brain: A multidisciplinary perspective, edited by Jean Decety, and Thalia Wheatley, 69-85. Cambridge: MIT Press.

Brick, Johnstone, and Glass A. Bret. 2008. "Support for a neuropsychological model of spirituality in persons with traumatic brain injury." International Bibliography of Theology and Religious Studies 43(4): 861-874.

Busenitz, Lowell W., and Jay B. Barney. 1997. "Differences between entrepreneurs and managers in large organizations: Biases and heuristics in strategic decision-making." Journal of Business Venturing 12(1): 9-30.

Butterfield, Jeremy. 1998, “Determinism and Indeterminism.” In Routledge Encyclopedia of Philosophy, edited by Edward Craig, 3: 33-39. London: Routledge.

Cohen, Adam, and Peter C. Hill. 2007. "Religion as Culture: Religious Individualism and Collectivism among American Catholics, Jews, and Protestants." Journal of Personality 75: 709-742. 
Colosimo, Jean-François. 2015. Les Hommes en trop. La malédiction des chrétiens d'Orient. Paris: Fayard.

Damasio, Antonio R. 2005. Descartes’Error: Emotion, Reason and the Human Brain. New York: Penguin Books.

Debè, Anna, and Simonetta Polenghi. 2019. “Agostino Gemelli (1878-1959) and mental disability: Science, faith and education in the view of an Italian scientist and friar.” International Journal of the History of Education 55: 429-450.

Dixon, Thomas. 2018. Nauka i religia. (Science and religion). Translated by Grzegorz Zienkiewicz. Łódź: Wyd. Uniwersytetu Łódzkiego.

Emmons, Robert A. 2005. “Emotion and Religion.” In Handbook of the Psychology of Religion and Spirituality, edited by Raymund F. Paloutzian, and Crystal L. Park, 235-252. New York: The Guilford Press.

Farman, Abou. 2019. “Mind out of Place: Transhuman Spirituality.” Journal of the American Academy of Religion 87(1): 57-80.

Feuillet. Michel. 2006. Leksykon symboli chrześcijańskich (Lexicon of Christian symbols). Poznań: Księgarnia św. Wojciecha.

Frankl, Viktor. 1997. Recollections: An Autobiography. Transllated by Joseph Fabry, and Judith Fabry. New York: Perseus Books Group.

Galanter, Marc. 2006. Spirituality and the Helthy Mind: Science, Therapy, and the Reed for Personal Meaning. Oxford: University Press.

Greenberg, Jeff, Sander L. Koole, and Tom Pyszczynski. 2004. Handbook of Experimental Existential Psychology. New York: Guilford Press.

Heller, Michał. 2016. Wierzę żeby rozumieć (I believe to understand). Kraków: Wyd. Znak i Copernicus Center.

Hood, Ralph W. Jr. 2008. „Mysticism and the paranormal.” In Miracles: God, Science, and Pychology in the Paranormal, edited by J.Harold Ellens, 3: 16-37. Westport, CT: Praeger.

Hood, Ralph W., and Jacob A. Belzen. 2013. "Research Methods jn the Psychology of Religion abd Spirituality.” In Handbook of the Psychology of Religion and Spirituality. Second edition, edited by Raymund, F. Paloutzian, and Crystal, L. Park, 75-93. New York: The Guilford Press.

Jan Paweł II. 1998. Fides et Ratio. Vatican: Libreria Editrice Vaticana.

Jaworski, Roman. 2006. „Propozycja psychologii bazującej na antropologii chrześcijańskiej” (A psychology proposal based on Christian anthropology). Roczniki Filozoficzne 9(1): 205-226.

Kahneman, Daniel, Paul Slovic, and Amos Tversky. 1982. Judgment under uncertainty: Heuristics and biases. Cambridge: Cambridge University Press. 
Krąpiec, Mieczysław, A. 2005. Człowiek jako osoba (Man as a person). Lublin: Polskie Tow. Tomasza z Akwinu.

Krokos, Jan, and Paweł Mazanka. eds. 2008. Some Questions of Classical Philosophy, Warsaw: Cardinal Stefan Wyszyński University Publishig.

Kurt, April, Dharani Babar, Peters Kai. 2012. "Impact of Locus of Control Expectancy on Level of Well-Being." Review of European Studies 4 (2): 124-136.

Küng, Hans. 1990. Projekt Weltethos. München: Piper Verlag.

Lamiel, James T. 2010. "Why was there no Place for Personalistic Thinking in 20th Century Psychology?” New Ideas in Psychology 28: 135-142.

Lines, Dennis. 2006. Spirituality in counselling and psychotherapy. London: SAGE Publications.

Lorenz, Konrad. 1966. On Aggression. Translated by Marjorie Kerr Wilson. New York: Harcourt, Brace \& World.

Makowski, Andrzej. 2017. “Odnowione misje ludowe narzędziem nowej ewangelizacji” (Renewed popular mission tool for the new evangelization). Roczniki Teologiczne 64(12): 99-116.

Newberg, Andrew I., and Stephanie K. Newberg. 2005. "Neuropsychology of Religious and Spiritual Experience.” In Handbook of the Psychology of Religion and Spirituality, edited by Raymund F. Paloutzian, and Crystal L. Park, 199-215. New York: The Guilford Press.

Nicholson, Ian. 1997. “Humanistic Psychology and Intellectual Identity: The 'Open’ System of Gordon Allport.” Journal of Humanistic Psychology 37: 60-78.

Palmieri, Patrick A., Grant N. Marshall, and Terry L. Schell. 2007. "Confirmatory Factor Analysis of Posttraumatic Stress Symptoms in Cambodian Refugees.” Journal of Traumatic Stress 20 (2): 207-216.

Paloutzian, Raymund, F. 2017. “Psychology of Religion in the World.” Revista Pistis Praxis 9 (1): 15-30.

Paloutzian, Raymund F., and Crystal, L. Park. eds. 2014. Handbook of the Psychology of Religion and Spirituality, Second Edition. New York - London: The Guilford Press

Persinger, Michael A. 1987. Neuropsychological Bases of God Beliefs, New York: Praeger Publishers.

Popielski, Kazimierz. 1994. Noetyczny wymiar osobowości (Noetic dimension of personality). Lublin: 1994: Wyd. Towarzystwo Naukowe KUL.

Popielski, Kazimierz. 2017. "Health and Illness as a Multidimensional Category.” In Study of Young People's Health in Russia, Belarus and Poland, edited by Natalia M. Rimashevskaya, and Kazimiez Popielski, 22-36. Lublin: Institute of Biofeedback and Nooosychomatic. 
Pargament, Kenneth, I. ed. 2013. APA Handbook of Psychology, Religion, and Spirituality. New York: Guilford.

Prinz, Jesse J. 2009. “The Normativity Challenge: Cultural Psychology Provides the Real Threat to Virtue Ethics.” Journal of Ethics 13: 117-144.

Rzepka, Jan. 1972. Uwarunkowania wolnej woli według Paula Chaucharda (Conditions of free will according to Paul Chauchard). Lublin: Wydawnictwo Towarzystwo Naukowe KUL.

Safir, Marilyn P., Helene S. Wallach, and Albert „Skip” Rizzo, editors. 2015. Future Directions in Post-Traumatic Stress Disorder: Prevention, Diagnosis and Treatment. Berlin: Springer.

Sarah, Charles, J., James E. Bartlett., Kyle J. Messick, Thomas J. Coleman III, and Alex Uzdavines. A. 2019. "Researcher Degrees of Freedom in the Psychology of Religion.” International Journal for the Psychology of Religion 29(4): 2-39.

Schjoedt, Uffe, Hans Stødkilde-Jørgensen, Armin W. Geertz, and Andreas Roepstorff. 2009. "Highly Religious Participants Recruit Areas of Social Cognition in Personal Prayer.” Social Cognitive and Affective Neuroscience 4(2):199-207.

Schwartz, Shalom H. 2011. "Values: Individual and Cultural.” In Fundamental Questions in Cross-Cultural Psychology, edited by Fons J. R. van de Vijver, Athanasios Chasiotis, and Seger M. Breugelmans, 463-493. Cambridge: Cambridge University Press.

Smith, Christian. 2010. "Five proposals for reforming article publishing in the social scientific study of religion (especially quantitative): Improving the quality, values, and cumulativeness of our scholarship.” Journal for the Scientific Study of Religion 49: 583-595.

Stokes, Geoffrey. 1998. Popper: Philosophy, Politics and Scientific Method. New York: Wiley \& Sons.

Sutcliffe, Steven J., and Ingvild S. Gilhus. 2013. "Introduction: “All mixed up” Thinking about Religion in Relation to New Age Spiritualities.” In New Age Spirituality: Rethinking Religion, edited by Steven J. Sutcliffe, and Ingvild S. Gilhus, 1-16. Durham, UK: Acumen.

Szydłowski, Piotr. 2018. “Dominant Styles of Thinking about Religion.” Psychology of Religion and Spirituality 10(1): 94-101.

Tennant, Christopher. 2007. “Prisoners of War.” In Encyclopedia of stress. Second Edition edited by George Fink, vol. 3: 223-226. New York: Academic Press.

Terelak, Jan F. 2009. “Pismo Święte jako źródło mądrości przednaukowej w zakresie radzenia sobie ze stresem na przykładzie Księgi Hioba: Studium przypadku” (The Bible as a source of pre-scientific wisdom in dealing with stress on the example of the Book of Job: Case study). In Czy rozum jest w konflikcie $z$ wiara?: 
WX rocznicę ogłoszenia Encykliki „Fides et ratio” (Is reason in conflict with faith?: On the tenth anniversary of the Encyclical announcement "Fides et Ratio"), edited by Jan Krokos, and Maria Ryś, 283-304. Warszawa: Wyd. Instytutu Papieża Jana Pawła II.

Thornton, Stephen. 2019. “Karl Popper.” In The Stanford Encyclopedia of Philosophy edited by Edward N. Zalta, 9-21. London: Routledge.

Total Fitness for the 21st Century Conference. Report Institute for Alternative Futures, San Diego (USA), December 6-9, 2009.

Truszczyński, Olaf, Jan F. Terelak, and Mariusz Turek. 2000. „Personality of Polish Soldiers and their Way Stress-coping during Bosnia Peacekeeping Mission.” Paper presented at the 36th International Applied Military Psychology Symposium (IAMPS) for the Changing mission for the 21st century, Split, Croatia, September 11-15.

Valent, Paul. 2007. "Holocaust, Stress Effects of.” In Encyclopedia of stress. Second Edition edited by George Fink, vol. 2: 342-346. New York: Academic Press.

Van Elk, Michiel. 2019. "Replication and Open Science in the Psychology of Religion: Editorial to the Special Issue.” Journal The International Journal for the Psychology of Religion 29(4): 227-229.

Waloszczyk, Konrad. 2016. “Religia i nauka w myśli Piere’a Teilharda de Chardin (1881-1955)" (Religion and Science in the Pierre Teilhard de Chardin Works: 1881-1955). Filozofia i Nauka. Studia Filozoficzne i Interdyscyplinarne 4: 81-94. Wasiukiewicz, Anna. 2015. Psychologia jak religia - religia jak psychologia (Psychology like religion - religion like psychology). Warszawa: Wydawnictwo Bollinari Publishing House.

Watts, Fraser. 2017. Psychology, Religion, and Spirituality: Concepts and Applications. Cambridge, UK: Cambridge University Press.

Wood, Benjamin T., Everett L. Worthington, Julie J. Exline, Ann M. Yali, Jamie D. Aten, and Mark R. McMinn. 2010. “Development, refinrement, and psychometric properties of the Attitudes Toward God Scale (ATGS-9).” Psychology of Religion and Spirituality 2: 148-167.

Żelazny, Mirosław. 2011. Filozofia i psychologia egzystencjalna (Philosophy and existential psychology). Toruń: Wyd. Naukowe UMK. 